\title{
Measuring Risk-adjusted Customer Lifetime Value and its Impact on Relationship Marketing Strategies and Shareholder Value
}

Research paper MS Number 115/03

by

Dr Lynette J. Ryals, MA (Oxon), MBA, FSIP, PhD*

Senior Lecturer in Marketing Centre for Advanced Research in Marketing

Cranfield School of Management Cranfield MK43 OAL

Tel: 01234751122

Fax: 01234751806

email:

lynette.ryals@cranfield.ac.uk

Professor Simon Knox, BSc, PhD Professor of Brand Marketing Centre for Advanced Research in Marketing

Cranfield School of Management

* Address for correspondence

Accepted by: European Journal of Marketing

Wordcount: 7874 (includes all references, figures and tables; text only $=6155$ words)

(C) 2004, Cranfield School of Management 


\section{Biographies}

\section{LYNETTE RYALS PhD MA (OXON) MBA FIIMR Senior Lecturer in Marketing}

Lynette joined Cranfield from a major management consultancy. She specialises in marketing measurement and IT in marketing, particularly in service businesses, and has just completed a $\mathrm{PhD}$ in customer profitability. Lynette began her career in the City as a fund manager and stockbroker trading UK equities, options and futures, and still lectures occasionally on finance issues. Lynette is a Registered Representative of the London Stock Exchange and is the only woman in the UK to have passed the Fellowship examinations of the Society of Investment Professionals. Her teaching assignments include the Cranfield MBA programmes as well as tailored corporate programmes and open programmes run at Cranfield. She was a guest lecturer for the Institute of Management in Nicosia, Cyprus, in 1993 and for the Chartered Institute of Management Accountants in Sri Lanka in 1995. From 2000-2002, Lynette was also Director of the Executive MBA programme and from 2002-2004 she was the Director of the MSc in Strategic Marketing.

\section{SIMON KNOX BSC PHD \\ Professor of Brand Marketing Cranfield School of Management}

Simon Knox is Professor of Brand Marketing at the Cranfield School of Management in the UK and is a consultant to a number of multinational companies including McDonald's, Levi Strauss, DiverseyLever, BT and Exel. Upon graduating, he followed a career in the marketing of international brands with Unilever plc in a number of senior marketing roles in both detergents and foods.

Since joining Cranfield, Simon has published over 100 papers and books on strategic marketing and branding and is a regular speaker at international conferences. He is a Director of the Cranfield Centre for Advanced Research in Marketing in the School and is currently leading a research team looking at the impact of Corporate Social Responsibility on Brand Management. He is the co-author of two recent books, "Competing on Value", published by FT Pitman Publishing in the UK, Germany, the USA and China, and "Creating a Company for Customers", FT Prentice-Hall, in the UK, Brazil and India. 


\section{Measuring Risk-adjusted Customer Lifetime Value and its Impact on Relationship Marketing Strategies and Shareholder Value}

\section{Abstract}

The calculations which underlie efforts to balance marketing spending on customer acquisition and customer retention are usually based on either single-period customer profitability or forecasts of customer lifetime value. In this paper, we argue instead for risk-adjusted customer lifetime value, which we term the economic value of a customer, as the means for marketing to assess both customer profitability and shareholder value gains.

We report on the empirical measurement of economic value of customers through a collaborative case study analysis of business-to-business relationships in the financial service industry. One direct consequence of measuring this risk and the economic value of key account customers was a customer portfolio review which led to changes in their relationship marketing strategies and improvements in shareholder value for the firm.

We conclude the paper by highlighting the limitations of our research and discussing selective customer retention through lifetime value analysis and a risk-adjustment process as the means for developing relationship marketing strategies.

This paper contributes to the field by extending the discussion on customer risk and demonstrating a method that managers can readily adopt to evaluate the risk of their customers. 


\section{Key Words}

Relationship marketing: risk-adjusted customer lifetime value: shareholder value analysis: longitudinal study.

\section{Introduction}

It is now widely accepted that the real purpose of the business is to create and sustain mutually beneficial relationships with selected customers. Since the emergence of relationship marketing in the 1980s, defined by Berry (1983) as "attracting, maintaining and enhancing customer relationships", there have been growing concerns about the validity of the traditional marketing approach which emphasises customer acquisition and a transaction-based view of sales (Levitt, 1986; Christopher, Payne and Ballantyne, 1991, 2003; Grönroos, 1994).

In contrast, relationship marketing (RM) offers firms the opportunity to build longterm customer relationships and to regard these relationships as a key marketing asset within the firm (Hunt, 1997; Kutner and Cripps, 1997; Varadarajan and Jayachandran, 1999). In balancing the need to develop customer acquisition and retention strategies, Reichheld and Sasser (1990) and Reichheld (1996) argue that firms can improve their profitability as customer retention increases; their research shows that a small improvement in customer retention rates from, say, $85 \%$ to $90 \%$, results in net present value profits rising from $35 \%$ to $95 \%$ amongst the businesses they examined. This research has been very influential in drawing attention to the critical role customer retention plays in developing a RM strategy. Whilst most firms now talk the rhetoric 
of RM, recent research amongst 200 of the UK's largest organisations suggests that about $90 \%$ of these firms are still not allocating their marketing budget appropriately (Christopher, Payne and Ballantyne, 2003). Eighty per cent of these firms tend to over-invest in customer acquisition, whilst $10 \%$ spend too much on customer retention activities. Only about $10 \%$, the "profit maximisers", consider they have the balance about right.

The "profit maximising" calculations which underlie efforts to balance marketing spending on customer acquisition and customer retention are usually based either on single-period customer profitability or on forecasts of customer lifetime value. However, maximising customer profitability, whether calculated for the single period or in net present value terms, may not be the most appropriate metric for measuring the value of customer relationships and for managing RM strategies (Ryals, 2002a). If marketing's contribution is to create shareholder value (Doyle, 2000), then customer relationships should be measured - and managed - for value rather than profit. Shareholder value analysis takes a longer term perspective and is a better measure of performance than profit since it enables marketers to consider investment risks in customer relationships as well as their returns (Rappaport, 1986; Cornelius and Davies, 1997).

\section{Measuring shareholder value}

Shareholder value measures the true returns to shareholders after all costs - including all costs of capital - have been deducted, whereas accounting profit deducts only the cost of debt, not the cost of equity (Stewart, 1991; Cornelius and Davies, 1997). To create shareholder value, investments in projects or in marketing assets must return 
more than the cost of capital (Mariotti, 1996; Cornelius and Davies, 1997). For this reason, the notion of risk is intrinsic to the concept of shareholder value. Shareholder value is created only when returns exceed the cost of capital. The cost of capital reflects risk. For this reason, discounted cash flow calculations which use a notional discount rate, rather than the true cost of capital, do not measure value creation. Applying shareholder value notions to marketing, this means that there are problems with both customer profitability and customer lifetime value measures. In addition, research shows that most companies do not measure customer profitability despite acknowledging its importance (Reinartz and Kumar, 2002). These issues will now be discussed.

\section{Measuring the profitability of customers}

The Economist Intelligence Unit (1998) found that customer profitability and customer lifetime sales were two of the top three most important customer-related performance measures that the companies in their survey would be monitoring in the future. However, they also found that most firms were measuring customer profitability in a top-down way based on the level of sales, the increase in order volume and the size of transactions. This approach, also known as RFM (Recency, Frequency and Monetary Value) is considered to be flawed (Reinartz and Kumar, 2002).

A frequently-encountered difficulty for companies wishing to measure customer profitability is that management accounting and reporting systems tend to reflect product profitability rather than customer profitability. Where product profitability is known, the direct product costs of customer purchases can be determined with 
reasonable accuracy. Indirect costs (principally the costs of sales, marketing and general administration [SGA]) are then allocated across the customer base, often in proportion to the total sales of each customer. However, this approach assumes each customer uses equivalent amounts of company time and effort in relation to sales revenue; whereas some customers are just more costly to serve than others, often due to their behaviour. For instance, new customers may demand more information about products and service levels, seek to customise the offer as far as possible and then buy on a limited basis as a trial measure. The costs to serve this customer, excluding acquisition costs, point towards an overstatement of profitability in the period. By contrast, customers who purchase on a regular basis and whose purchasing habits are routine and predictable, are relatively easy to serve. Thus, the profitability of such customers stemming from a proportional allocation of costs can be understated. The higher the proportion of indirect costs (in relation to product costs), the more misleading a simple proportional allocation becomes. Howell and Soucy (1990) show that SGA costs have grown significantly and now represent $20-40 \%$ of total costs in Fortune 500 companies.

\section{Customer Profitability: Looking Forwards, not Backwards}

A fundamental problem which applies to all current (and historical) customer profitability analysis is that it does not necessarily act as a guide to the future (Wilson, 1996). Basing relationship marketing strategies on such data could be damaging to longer-term value creation. Once a firm has recognised the importance of building customer relationships, marketing and sales need to decide which customers they want to build closer relationships with in the future. As companies move towards one-to- 
one marketing, they need to develop a longer-term view of the value of their customer relationships than current data can provide (Peppers and Rogers, 1994; 1997; 1998). Effectively, relationship marketers need to predict the future purchasing behaviour of key customers to arrive at their Customer Lifetime Value (CLTV; Ryals, 2002b). CLTV looks at what the retained customer is worth to the organisation now, based on the predicted future transactions and costs. Looking forward to the value of future purchases and costs, expressed as the present value of a stream of future profits, fits more comfortably with the development of a RM approach which is concerned with unlocking value for the firm and its key customers. Forward-looking customer lifetime value measures are also more consistent with the principles of shareholder value creation.

To calculate the lifetime value of a customer (CLTV), three sorts of information are needed: the anticipated lifetime of the customer relationship in months or years; the profit in each future period adjusted for any customer-specific capital costs, such as marketing and customised services; and a discount rate (Figure 1).

\section{[Take in Figure 1]}

However, even if CLTV calculations are reliable and show a positive CLTV, i.e. the firm can accurately predict that a customer's future spending patterns exceed the cost of acquiring future sales, it is still possible to destroy shareholder value as the relationship develops (Reinartz and Kumar, 2002). 


\section{Customer Lifetime Value and Shareholder Value}

CLTV analysis suggests that the value of a relationship with a customer can be increased either by increasing the amount of profit (by increasing the revenue from the customer and/or decreasing costs to serve), or by extending the relationship lifetime. Customers at the beginning of their relationship lifetime will need a different RM strategy to those approaching the declining stage of their relationship lifetime. Retail banks understand this principle well; they have identified students as potentially high value customers over a lifetime, even though in the short term they may be unprofitable. So, CLTV calculations, often used to measure the profit impact of customer retention strategies, provide a better guide for customer strategy than current period profit (Dorman and Hassan, 1996).

However, neither single-period profitability nor CLTV effectively account for the risk in developing a customer relationship. This is the reason why seemingly profitable activities (such as investments in customer relationships) can be misleading, showing apparent growth whilst providing minimal or negative returns to shareholders (Rappaport, 1986). It has been argued that shareholder value measures that include risk measurement should be applied to the calculation of the value of customers (Mariotti, 1996; Uyemara, 1997). We would argue, therefore, that an adjustment to CLTV is needed to offset the profits earned against the risk of investing in the relationship. So, in assessing customer risk, we need to anticipate risk in the revenue streams and the costs-to-serve a customer, particularly those customers who have been designated for significant investment for their future growth potential. The 
combination of forecast CLTV and future customer risk we term the economic value of a customer.

\section{The Economic Value (EV) of a Customer}

In the same way that projects and investments must yield more than the cost of capital to create shareholder value (Stewart, 1991; Cornelius and Davies, 1997), the riskadjusted return from a customer must more than compensate for the investment made in that customer if marketing is to contribute to shareholder value (Mariotti, 1996; Uyemara, 1997). Such customer investments might include developing bespoke services, the cost of time taken to understand their business, and the support of a customer development team in managing the relationship. When companies apply this thinking to their customer portfolio, it is likely they will find they have some customers who create value but others who destroy shareholder value (Figure 2).

\section{Take in Figure 2}

Doyle (2000) argues that it is this type of economic value measure which enables relationship marketers to develop a better understanding of shareholder value and its links to customer retention and lifetime value. As a key asset of the firm, customer relationships need investment, just as tangible assets do, despite the fact they are not "owned" in the same way (Wayland and Cole, 1994). In fact, if they choose, customers can defect to competing suppliers. Thus, accounting for value in a customer relationship not only implies a value exchange over time (Slywotzky, 1995) 
but also a risk assessment of individual customers or customer segments (Dhar and Glazer, 2003).

\section{Modelling the EV of a customer}

The model we use in this paper to measure the economic value of a customer relationship is derived from the literature on relationship marketing and customer retention (e.g. Reichheld and Sasser, 1990; Christopher, Payne and Ballantyne, 1991, 2003; Grönroos, 1994; Hamilton, Howcroft and Saunders, 1995; Reichheld, 1996, 2000; Jenkins, 1997) and the risk literature related to shareholder value analysis (Stewart, 1991; McTaggart, Kontes and Mankins, 1994; Mariotti, 1996; Cornelius and Davies, 1997; Uyemara, 1997) and is shown in Figure 3:

\section{[Take in Figure 3]}

Next, we apply these principles to show how CLTV and EV are calculated in an international insurance company and what impact this has in developing the firm's RM strategies and shareholder value. The company in question is Zurich (London) ${ }^{1}$, a subsidiary of the Zurich-based international insurer, and its business is to provide insurance cover, from fire to loss-of-profits, for its corporate clients.

\section{Developing the research models at Zurich (London)}

\footnotetext{
${ }^{1}$ We should make it clear that Zurich (London) is the brand name, not the name on the company's insurance contracts.
} 
In order to overcome the problems of privileged access (Balmer, 2001), the researchers first presented their ideas on measuring the CLTV and EV of customers to the senior management of Zurich. In extended discussions with the firm, the proposed methodological approach of collaborative case study analysis and the benefits derived from such collaboration were endorsed and the agreement to proceed given.

Given the complex nature of the research task, we were most anxious to establish a research methodology and protocol which not only enabled the collection of rich data (Carson, Gilmore, Perry and Gronhaug, 2001), but also required the active involvement of participating managers to help generate this data in conjunction with the researchers (Knox and Bickerton, 2003).

Zurich was chosen as the participating company for a number of different reasons:

- As an insurance company with a portfolio of international customers, the firm's Customer Delivery Team has detailed customer information on the key accounts it managed and understands the notion of customer risk as well as returns.

- The Customer Delivery Team, although newly-formed, is accustomed to working with customers in the long term and was able to forecast future revenues and costs, adjusted for risk and the cost of capital, even where it did not already do so.

- As a new team, the idea of collaborative research which involved full participation, but which held uncertainty both in process and outcome (Gummesson, 2000) was appealing to them. The view of the 5 executives directly involved in the project (and the auxiliary team members drawn from senior actuaries, senior managers and account managers of non-key accounts) was that 
an improved understanding of the value of their customers would help strengthen customer plans, improve resource allocations and contribute to more effective relationship marketing strategies.

\section{Data Capture and the Unit of Analysis}

Throughout the project lifetime of 18 months, both models were discussed, developed and agreed through researcher intervention with the Customer Delivery Team (CDT) and the auxiliary members, as appropriate. This included workshops, face-to-face interviews and the iteration of 22 spreadsheets $^{2}$ to arrive at CLTV and the final estimation of the economic value of each key account. In total, researcher intervention occurred on 14 separate occasions, prior to debrief and the $\mathrm{i}$ implementation of revised RM strategies which the researchers subsequently returned to discuss.

The accuracy of quantitative data was checked in two ways. Successive versions of the spreadsheet (Microsoft Excel) were fed back to members of the CDT and their views solicited. This led to considerable changes in the forecasts. Other quantitative data were checked for accuracy of calculation and transcribed by a third party who had data entry experience.

Of Zurich's several hundred corporate customers, twelve were regarded as the main key accounts and generated approximately $17 \%$ of total revenue. It is these key accounts that form the unit of analysis and are drawn from eight industry sectors,

\footnotetext{
${ }^{2}$ Once the models were established after 22 iterations, i.e. earlier versions of the spreadsheet were discounted as items were introduced or removed, the process of estimating CLTV or economic value for each account was the same.
} 
ranging from I.T. and Telecoms, chemicals and pharmaceuticals, business services, hotels and leisure, to a charitable foundation. In this paper, two of these accounts are discussed in detail to illustrate how CLTV and EV are calculated.

\section{Calculation of CLTV}

Given that the nature of the insurance business is to provide cover against claims, the research models have been adapted to reflect the specific nature of the industry. However, they are generalisable: the revenue items are analogous to product or service purchases in other industries and the cost items are generalisable to product costs and costs-to-serve. In total, three calculations are identified as necessary to capture the CLTV value of a customer at Zurich. They are shown below in the composite model (figure 4 ) in the following sequence (1a $\rightarrow 2 \rightarrow 3 \rightarrow$ CLTV):

\section{[Take in Figure 4]}

The CLTVs of the 12 key account relationships were developed individually. However, for the sake of parsimony, we will only report our research findings for two of these accounts: Customer B, a hotel group, and Customer L, a charitable foundation. These customers have been selected for three main reasons:

- Both customers had been insured through Zurich for 6 and 16 years respectively which meant each relationship was in a mature phase (no other key account had a longer history with the company).

- The perception of the value of both customer relationships (estimated as perceived profitability before model development, and their economic value afterwards) 
changed during the project lifetime. This led to direct changes in how both accounts were managed and in the RM strategies adopted.

- The team felt confident that their forecasts for these accounts could be estimated with some accuracy since their insurance requirements and claims behaviours were reasonably predictable.

\section{1a. Revenue Forecasts for Customers B and L}

The average actual relationship lifetime of the CDT's customers was 4 years 3 months. Therefore, the calculations of CLV and EV are based on a relationship lifetime of 4 years (current year plus three).

Revenues are derived from two sources:

- Net Earned Premiums: the premiums after reinsurance, i.e. the income received on the actual proportion of the risk that Zurich is to bear. If the insurance risk of the customer increases, the gross premium will increase; however, Zurich may decide to reduce its exposure to this insurance risk by reinsuring a greater proportion of the gross premium. This would have the apparent effect of reducing the revenues from a riskier customer. To remove this complication, the net earned premiums only are considered, and the costs of reinsurance are excluded from the calculation.

- Other revenues: fees received by Zurich for managing relationships with captive insurance companies (that is, insurance subsidiaries of non-insurance companies); for other services such as risk consultancy; and from the sales of new products, such as software products. 
These revenue forecasts are shown in Figure 5:

\section{[Take in Figure 5]}

Revenue growth for both accounts depends upon growth in net earned premiums, which is relationship-dependent. As commitment and trust builds, the firm anticipates enjoying a greater share of insurance expenditure from the client (Coyles and Gokey, 2002). Forecasts for Customer B show this effect strongly; whilst for Customer L it is more modest.

\section{Cost Forecasts}

The costs-to-serve for each key account consists of two direct and one indirect cost. These costs are:

Direct Costs

- Underwriting services: costs and salaries. These were the direct sales and service costs of looking after the customer.

- Cost of Claims. This is the cost of processing claims (number of claims x cost per claim).

Indirect Cost

- Network Costs. These were costs of issuing policy documents and internal processing within the company.

The cost forecasts for Customers B and L are shown in Figure 6.

\section{[Take in Figure 6]}

The differing costs-to-serve between Customer B and Customer L need a brief explanation: 
Underwriting services represent the amount of time spent by the CDT and senior colleagues in managing the relationship and resolving problems. On larger and more complex accounts, more time is needed for RM purposes. In the case of Customer B and Customer L, the absolute amounts are very different but, proportional to revenues from net earned premiums, they are relatively similar.

Claims costs, the costs of processing claims, are determined by the number of claims generated by the client which, in turn, depend upon the type of insurance written and the risk management ability of the client. Many small claims are more costly to process than a single claim, no matter how large the latter may be. For its size, Customer L has a relatively high claims processing cost.

Network costs are Zurich's central costs associated with issuing documents, contracts etc. These costs depend on the number and complexity of contracts which, in turn, reflect the number of insurance products that the customer purchases and their internal organisational structure (number of different geographical areas covered, number of business units, degree of centralisation of risk management). Customers B and L both have network costs proportional to the size of their business with Zurich. However, network costs were expected to increase for B because of some anticipated changes in its business structure.

\section{Present Value Calculations}


The CLTVs for customers B and L are then calculated from revenue and cost forecasts adjusted for present value using Zurich's weighted average cost of capital (4.8\%). Figure 7 shows that the CLTV of Customer B is $£ 1,237,000$ and Customer $\mathrm{L}$ is $£ 199,000$.

\section{[Take in Figure 7]}

Whilst both customers B and L remain profitable, as their CLTV calculations show, the unexpected discovery that other key accounts in the portfolio were unprofitable immediately raised a number of issues about the strategies that were used to manage them. This, in turn, led to a consideration of the risks associated with managing key accounts and, hence, to the economic value (EV) of the customer.

\section{From CLTV to the EV of a Customer}

In our composite model (figure 4), EV can be derived from CLTV calculations by assessing the risk in customer revenue streams on a customer by customer basis (1a $\rightarrow 1 \mathrm{~b} \rightarrow 2 \rightarrow 3 \rightarrow \mathrm{EV})$. Two risk adjustments are made in our model.

\section{1b. Risk-adjusting the revenue forecasts}

The risk of the customer can be considered to be the volatility of future revenue streams. To reflect this, we developed measures against two specific aspects of customer risk profiling: customer-specific claims risk, the proportion of insurance claims as a $\%$ of net earned premium which is also expressed as a probability; and relationship risk, a forecast probability of customer retention. 
Unlike the portfolio claims risk used to calculate CLTV (figure 5; 67\%), the claims risk is now customer-specific and therefore part of economic value. Customer-specific insurance claims risk may be a significant factor in EV. Insurance companies are exceptional in that the profits from their customers are limited by the premium but massive losses are possible with large claims. This contrasts with some other commercial relationships where profit is more variable than costs.

The customer-specific claims risk was calculated by the CDT based on known previous claims experiences and forecasts of products purchased by the customer. In the cases of Customers B and L, the risk of higher claims by Customer L (60\% compared to $30 \%$ for B on an annual basis in figure 8) may seem curious at first, since $\mathrm{L}$ is a charitable foundation whereas B is a leisure company. However, the differences in claims risk relate to the type of insurance written, the CDT's understanding of the customer and, particularly, the risk management process within the customer business. Customer B has a risk management team whereas Customer L does not; therefore, the internal risk management process is stronger for B than for L, making it a lower claims risk for Zurich. These customerspecific claims risks are applied only to the Net Earned Premium (NEP) since the other revenue streams are independent of claims.

Relationship risk is based on a prediction by the CDT of the likelihood that that key customer would be retained, year by year. The forecast probability of retention is applied to all revenues, including net earned premiums and other 
revenues (fronting fees, fee-based income and product sales are grouped as 'other revenues' for simplicity in figure 8).

We calculate the economic value of both accounts by bringing together the riskadjusted revenues, subtracting the costs, and adjusting to present value by Zurich's weighted average cost of capital. In this case, costs to serve are not affected by the risk of the customer, although in applications of the model to other situations they may be.

The EV of Customer B is shown to be $£ 1,902,000$ (Figure 8) compared to a CLTV of $£ 1,237,000$ (Figure 7), and the EV of Customer L is $£ 165,000$ against a CLTV of $£ 199,000$. Customer B is low risk and, whilst there is a slight risk of defection in later years, the economic value of this customer reflects the fact that its claims risk profile is less than half of the portfolio average. Thus, the CLTV of Customer B understates its true economic value. Customer L has a slightly higher risk of defection and a claims risk that is close to the portfolio average; for these reasons, Customer L's CLTV overstates its economic value.

\section{[Take in Figure 8]}

The greater the divergence of customer risk from the portfolio norm, the greater the difference between CLTV and EV. We would argue, therefore, that the economic value calculations shown above are particularly important for high-risk customers as they may be considerably less valuable to the organisation than their CLTV would suggest. 
The flat, risk-adjusted revenue forecast for Customer $\mathrm{L}$ is in marked contrast to the forecast growth in revenues for this account based on projected sales. Moreover, Customer L has a higher proportion of revenues coming from fronting fees, which are less volatile than net earned premiums.

The differences between risk-adjusted and non risk-adjusted revenues raise issues about the real value of customers, as does the contrast between CLTV and EV. Thus, the measurement of customer risk and the EV of a customer is important in developing appropriate customer strategies. This is certainly true for Zurich, both at a customer portfolio level and at individual account level, and for most other firms who manage their customers (or customer segments) through RM strategies. We discuss both aspects of the Zurich's key account strategy in the next section.

\section{Managing Zurich's Key Account Portfolio for EV}

In this section, we consider the impact of calculating economic value on the key account portfolio as a whole. Moving from perceived profitability and CLTV to the $\mathrm{EV}$ of the customer results in marked differences in the relative profitability of key accounts as our data show (Figure 9). Accounting for risk generally indicates a dampening of the future profitability of existing customers which runs counter to some previous studies on the impact of customer retention (for example, Reichheld, 1996) and the supposition that more would be known about longer duration customers. It seems that these beneficial effects of customer retention are being eroded by the negative effects of the 'pincer' exerted by long-term customers of 
downwards price pressure coupled with upwards demands for claims and service (Kalwani and Narayandas, 1995; Reinartz and Kumar, 2002).

\section{[Take in Figure 9]}

Three new key accounts (not shown in Figure 9) had been won during the period and they now occupy rank places 1,2 , and 3 , indicating that new accounts tend to be more profitable. Our research undoubtedly influenced the behaviour of the CDT as they are now clearer about the costs to serve a customer; this impacts on their negotiations with prospective customers in that they built in these forecast costs into their proposals. Thus, new customers are being acquired on more favourable terms (to Zurich) than had prevailed with existing customers. This is a particularly striking development as it is taking place at a time when insurance rates in the market are generally softer than they have been in the previous few years.

Based on its EV, rather than CLTV, Customer B's relative position in the portfolio is slightly reduced $\left(6^{\text {th }}\right.$ compared to $\left.4^{\text {th }}\right)$. Nonetheless, it is still a big and important customer to Zurich so the management of this account has not changed substantially as a result of the analysis. However, Customer L appears to be considerably less valuable than the CDT had first thought. This was noticeable after the CLTV calculation and even more so after its EV had been measured and compared to the rest of the key account portfolio. Prior to our research, this account was perceived to be the most profitable of all. This finding persuaded the key account manager for Customer L to be more cautious in the amount of time and resource committed to the account. 
Risk is a particularly important issue when considering customers $\mathrm{C}$ and $\mathrm{H}$, not only because of the way risk is managed within each company but also from an industry perspective as both their sectors are inherently risky. Customer C's position improves from $12^{\text {th }}$ to $7^{\text {th }}$ because risk is exceptionally well managed within the company. So, although the industry itself was as risky as Customer H's, customer C's risk profile increases its EV. In contrast, Customer $\mathrm{H}$ does not have a significant risk management capability, which results in a downgrade in its EV.

Finally, a mention of Customer J which remained unprofitable throughout our research, particularly when assessed for risk. The CDT members reviewed their relationship with Customer J very carefully indeed but concluded that, as a very high profile company and brand name with the ability to attract others, it is worthwhile retaining as a key account for reference and referral purposes (Ryals, 2002a; Wilson 1996).

\section{Changes to Zurich's Relationship Marketing Strategy}

Our research suggests that the EV (and lifetime value) of the customer relationships which drive company profitability may not be fully understood. Figure 9 illustrates two related aspects of the problem which can affect shareholder value: differing opinions about the relative profitability of customers amongst senior management based on their own judgements; and the differences between perceived customer profitability (where a consensus exists) and their actual profitability as revealed by research of this type. The implication we draw from this is that inappropriate amounts of management time and resource may be allocated to customers whose economic 
value does not justify such expenditure. Conversely, other customers with greater economic value may be underinvested. The appropriate relationship management strategy will depend on whether, and to what extent, the risk of defection can be reduced and the EV of the customer thereby increased. In some cases, the optimal strategy would be to reduce the costs to serve low EV customers and use the resources released to acquire other, higher value customers. In other cases, the most effective strategy would be to analyse the components of defection risk and manage the relationship so as to reduce the risk and increase the $\mathrm{EV}$ of the customer.

Upon concluding our research, Zurich's CDT felt that they had sufficient insight and confidence to make certain changes to their customer relationship marketing practices. For instance, customers $\mathrm{N}$ and $\mathrm{O}$, now regarded as relatively unprofitable, were moved to the care of industry teams handling major accounts (but not key accounts) so the costs to serve them could be lower. In the case of Customer N, this decision was made not just on cost grounds but also from an understanding that the account was low risk and low maintenance and did not warrant resourcing by key account management.

Generally, the reaction of the CDT to our research has been to adjust their service levels and they are increasingly seen as tougher negotiators by their professional intermediaries. They are now able sometimes to charge for services that had previously been provided free to existing customers. The senior management involved in our research commented at debrief that they had become more concerned about obtaining a return on incremental marketing effort and were less likely to provide additional services to customers without asking for payment in return. This change in 
behaviour impacts the costs-to-serve and helps contain cost inflation across key accounts.

Another change to their RM strategies concerns resource allocation and how key account managers spend their time. Overall, the average probability of customer retention amongst key accounts is about $75 \%$ annually. However, this average conceals considerable variations. In cases where the probability of customer retention appears relatively low, a change in strategy is called for. As a consequence, the team now discusses how they should allocate their time against these particular accounts. If they can rectify the problem with the relationship and increase the probability of retention, then this is their priority. If this does not seem possible, account managers then ensure that they spend enough time on business development activities in order to attract new customers to replace these accounts in the event that they defect.

\section{Limitations and future research directions}

As we have mentioned above, many aspects of the model and of the research design are of general applicability, especially the development of CLTV and of the risk element in customer relationships. Following Uyemara (1997) and Mariotti (1996), we would argue for the application of shareholder value measures to CLTV, particularly the measurement of customer risk. Although our research and the dearth of literature on the subject of customer risk suggest that the concept is not well understood, customer risk is a live topic for marketing (Dhar and Glazer, 2003). 
In opening up this whole field of customer risk and EV to discussion, we must acknowledge a number of limitations in our research design. One such limitation is that we have restricted the definition of relationship risk so that it is concerned principally with customer defection over time. By our own admission, this is a circumscribed view of customer risk. Even in the insurance industry, which understands the notion of risk as well as returns, the tools to measure certain aspects of customer risk are in their infancy. Future researchers may attempt to incorporate and quantify other customer risks, such as change of ownership and leadership, major changes of strategy or, topically, fraud and default risk. This broadening of customer risk measures would serve to improve our understanding of the EV of customers.

A second limitation concerns the specialized nature of the research task we have undertaken: working with a senior management team across a small sample of customers in the insurance industry. We recognise that customer risk differs according to industry circumstance and competitive intensity, and the reasons why customers themselves are considered high, medium or low risk can vary over time as management gain insights about their behaviours through their R.M. practices. In response to this, there are a number of future research directions that could be followed, such as measuring the EV of customers within different industries or researching how a firm's relationship marketing strategies can be adapted according to the risk profiles of their customers over time, and the impact this has on the EV of the customer.

A third limitation that became a frustration was our inability to collect full data on all the customers studied; this was a consequence of the longitudinal research process we 
used. Key account customers arrived and departed during the project; in fact, the universe of key account customers studied amounted to 18, although we have been able only to present data on 12 , and full data on 10 of these. Changes to the key customer portfolio during the research meant that direct comparisons were not always possible; however, we felt that this limitation was acceptable given that the longitudinal research design made it possible for us to change the system and the ways in which customer relationships were perceived and managed. Future researchers may take a larger customer sample, possibly across market segments rather than in a key account context, and EV measures made over a shorter time period so that any effects from customer defection can be reduced.

\section{Conclusions}

In this paper, we set out to argue that there is still a significant gap between the R.M. strategies practised by most companies and the espoused strategies called for by Reichheld and others which focus more on customer retention than acquisition.

If there is to be a greater emphasis on customer retention, we maintain (against Reichheld's general view) that it should be focused on the customers with the greatest lifetime value rather than simply increasing customer retention overall. Any discussion of differential customer retention and lifetime value immediately raises the issue of how the value of such a customer relationship is to be measured and managed. 
Drawing on the literature on shareholder value, we argue that customer lifetime value measures should be adjusted for risk in order to determine the EV of the customer. Working with Zurich's Customer Development Team in business-to-business insurance, we develop a customer lifetime value analysis and a risk-adjustment process to calculate the EV of the firm's key accounts.

The results of our research demonstrate that the measurement of the EV of a customer is both viable and implementable as a management tool, impacting on both relationship marketing strategies and shareholder value gains. The future challenge for researchers will be adapting these principles of risk-adjusted CLTV for use in other industry sectors where relationship marketing practices and CLTV measures are becoming the norm.

\section{References}

Balmer, J. M. T. (2001), “Corporate Identity, Corporate Branding and Corporate Marketing: Seeing through the Fog", European Journal of Marketing, Vol. 35 No. 34, pp. 249-291.

Berry, L.L. (1983), "Relationship Marketing” in L. Berry, G.L. Shostack and G.D. Upah (Eds), Emerging Perspective on Service Marketing, American Marketing Association, Chicago, pp. 25-28.

Carson, D., Gilmore, A., Perry, C. and Gronhaug, K. (2001), Qualitative Market Research, Sage, London. 
Christopher, M., Payne, A. and Ballantyne, D. (1991), Relationship Marketing, Butterworth-Heinemann, Oxford.

Christopher, M., Payne, A. and Ballantyne, D. (2003), Relationship Marketing: Creating Stakeholder Value, Butterworth-Heinemann, Oxford.

Cornelius, I and Davies, M. (1997), Shareholder Value. Financial Times Publishing, London.

Coyles, S. and Gokey, T.C. (2002), "Customer Retention is not Enough", The McKinsey Quarterly, Vol. 23, pp. 81-89.

Dhar, R. and Glazer, R. (2003), "Hedging Customers”, Harvard Business Review, Vol. 81 No. 5, pp. 86-92.

Dorman, J. and Hassan, M. (1996), “Turning Lead into Gold”, Bank Marketing, Vol. 28 No. 11 , pp. $28-32$.

Doyle, P. (2000), "Valuing Marketing's Contribution”, European Management Journal, Vol. 18 No. 3, pp. 233 - 245.

Economic Intelligence Unit (with Andersen Consulting), (1998), Managing Customer Relationships - lessons from the leaders. Report.

Grönroos, C. (1994), “From Marketing Mix to Relationship Marketing: Towards a Paradigm Shift in Marketing”, Management Decision, Vol. 32 No. 2, pp. 4-20.

Gummesson, E. (2000), Qualitative Methods in Management Research, $2^{\text {nd }}$ Edition, Sage, London.

Hamilton, R., Howcroft, J.B. and Saunders, J. (1995), “Customer retention: a behavioural model", IMA Journal of Mathematics Applied in Business and Industry, Vol. 64 No. 4, pp. 363-342.

Howell, R.A. and Soucy, S.R. (1990), “Customer profitability: as critical as product profitability", Management Accounting, Vol. 72 No. 4, pp. 43-47. 
Hunt, S.D. (1997), “Competing through relationships: grounding relationship marketing in resource-advantage theory", Journal of Marketing Management, Vol. 13 No. 5, pp. 431-445.

Jenkins, M. (1997), The Customer-Centred Strategy: Thinking Strategically about your Customers, Pitman, London.

Kalwani, M. U. and Narayandas N. (1995), "Long-term manufacturer-supplier relationships: do they pay off for supplier firms?" Journal of Marketing, Vol. 59 No. 1, pp.1-16, January.

Knox, S. D. and Bickerton, D. (2003), "The six conventions of corporate branding", European Journal of Marketing, Vol. 37 No. 7-8, pp.998-1016.

Kutner, S. and Cripp, J. (1997), "Managing the customer portfolio of healthcare enterprises", The Healthcare Forum Journal, Vol. 4 No. 5, pp. 52-54.

Levitt, T. (1986), The Marketing Imagination, The Free Press, New York.

Mariotti, J. (1996), "Beyond activity-based costing: try customer-based profitability accounting", Industry Week, Vol. 245 No. 22, p.29

McTaggart, J.M.; Kontes, P.W and Mankins, M.C. (1994), The Value Imperative Managing for Superior Shareholder Returns, Free Press, New York.

Peppers, D. and Rogers, M. (1994), The One-to-One Future, Piatkus, London.

Peppers, D. and Rogers, M. (1997), Enterprise One-to-One, Piatkus, London.

Peppers, D. and Rogers, M. (1998), “Customer Value”, CIO Magazine, Vol. 11 No. 23, pp. 82-83.

Rappaport, A. (1986), Creating Shareholder Value: The New Standard for Business Performance, Macmillan, London.

Reichheld, F. (1996), The Loyalty Effect, Harvard Business School Press, Boston, MA. 
Reichheld, F. and Schefter, P. (2000), "E-Loyalty: Your Secret Weapon on the Web", Harvard Business Review, Vol. 78 No. 4, pp.105-114, Jul-Aug.

Reichheld, F. and Sasser Jr., W.E. (1990), “Zero Defections: Quality Comes to Services", Harvard Business Review, Vol. 68 No. 5, pp. 105-111, Sept-Oct.

Reinartz, W.J. and Kumar, V. (2002), “The Mismanagement of Customer Loyalty”, Harvard Business Review, Vol. 80 No. 7, pp. 86-94, July.

Ryals, L.J. (2002a), “Are your customers worth more than money?” Journal of Retailing and Consumer Services, Vol. 9, pp. 241-251.

Ryals, L.J. (2002b), “The Total Value of the Customer and Targeted Marketing Strategies", unpublished PhD thesis, Cranfield School of Management, UK.

Slywotsky, A.J. (1995), Value Migration, Harvard Business School Press, Boston, MA.

Stewart III, G.B. (1991), The Quest for Value. HarperBusiness, New York.

Uyemara, D.G. (1997), "EVA: a top-down approach to risk management”, Journal of Lending \& Credit Risk Management, Vol. 79 No. 6, pp. 40-47.

Varadarajan, P.R. and Jayachandran, S. (1999), "Marketing Strategy: An Assessment of the State of the Field and Outlook", Journal of the Academy of Marketing Science, Vol. 27 No. 2, pp.120-143, Spring.

Wayland, R.E. and Cole, P.M. (1994), “Turn customer service into customer profitability; to maximise your firm's value, think of customers as a business asset”, Management Review, Vol. 83 No. 7, pp. 22-24, July.

Wilson C. (1996), Profitable Customers, Kogan Page, London. 
Figure 1: Customer Lifetime Value (CLTV) Model

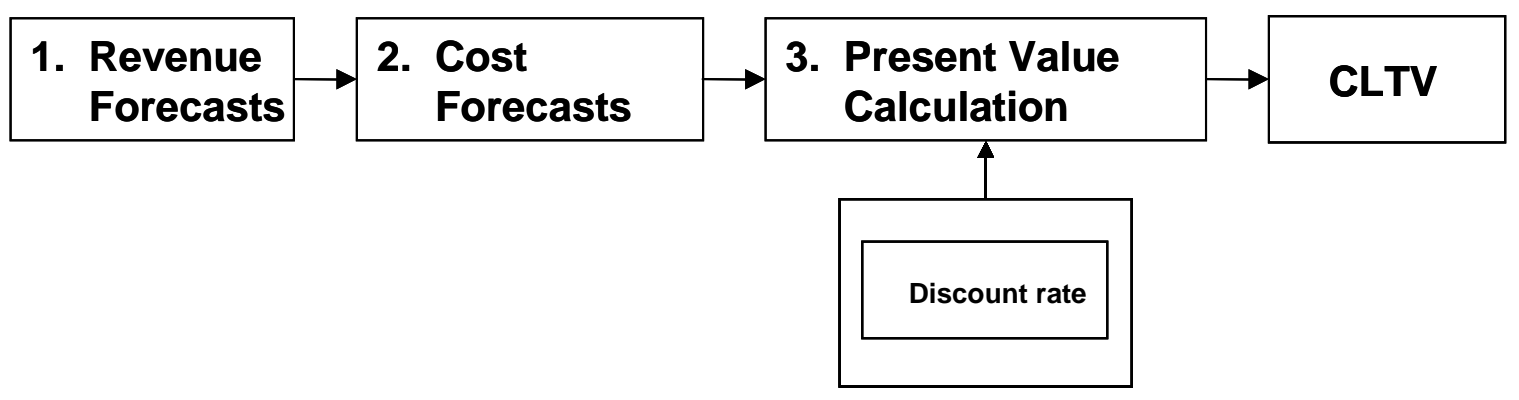


Figure 2: A Firm's Customer Portfolio

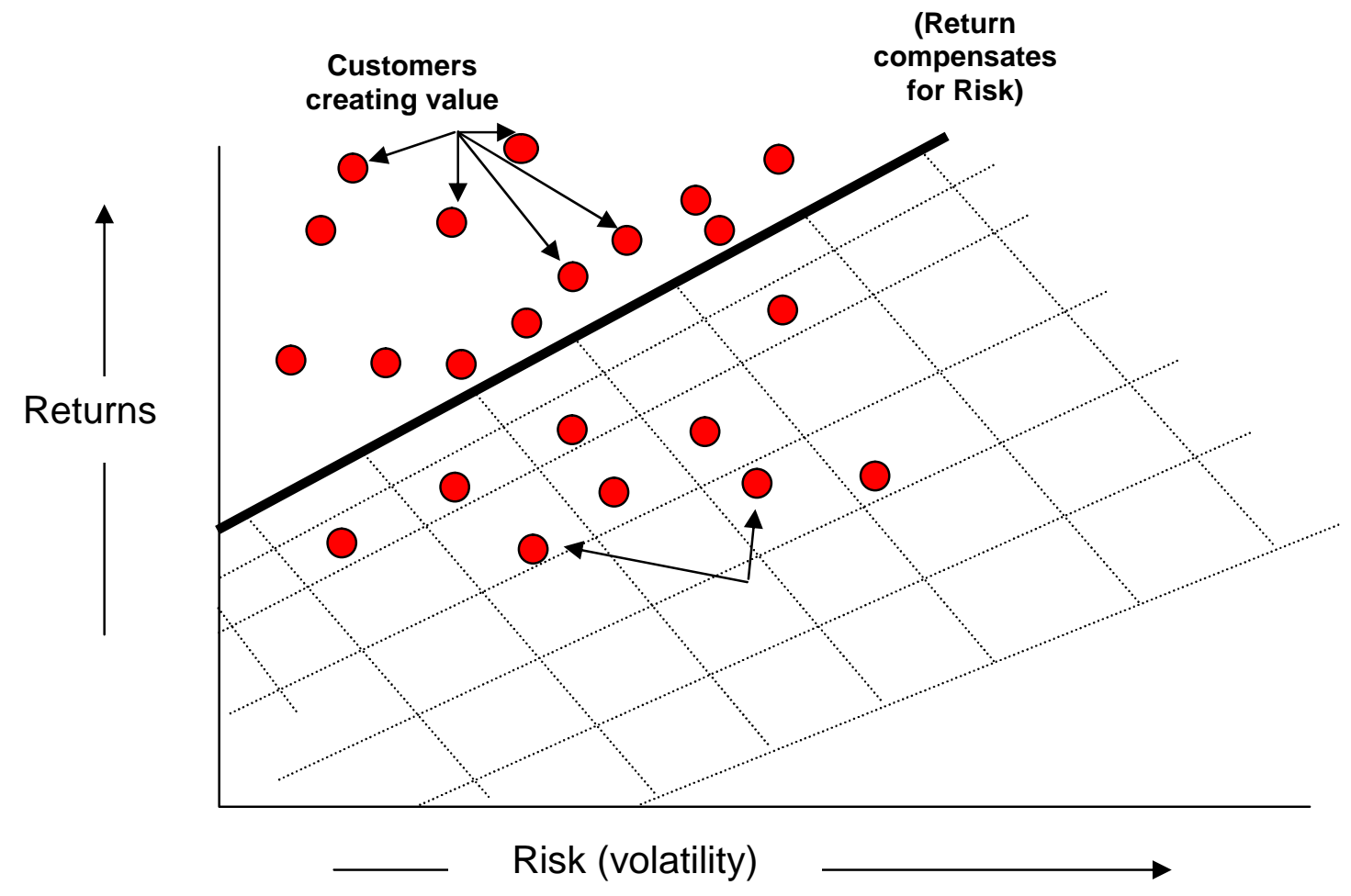


Figure 3: Customer EV model

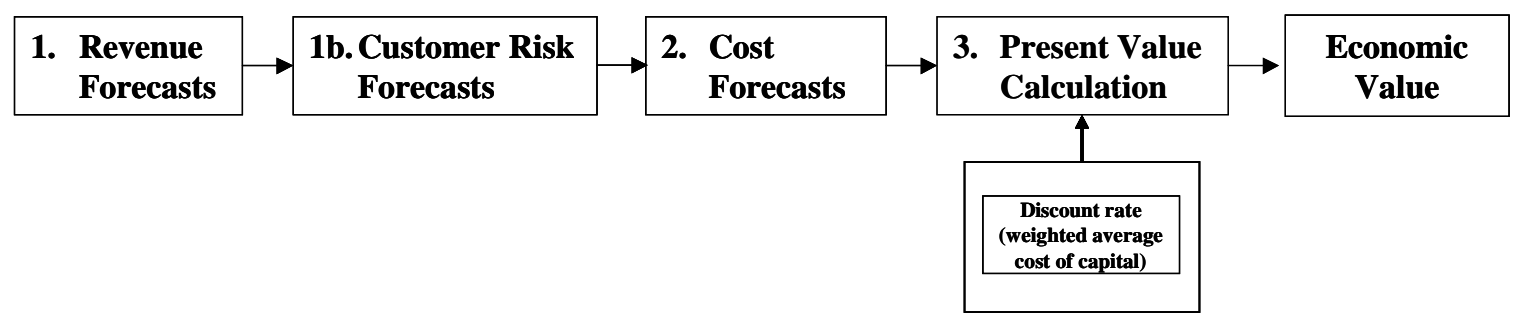


Figure 4: A Composite Model for Calculating CLTV and $\mathrm{EV}^{3}$ at Zurich

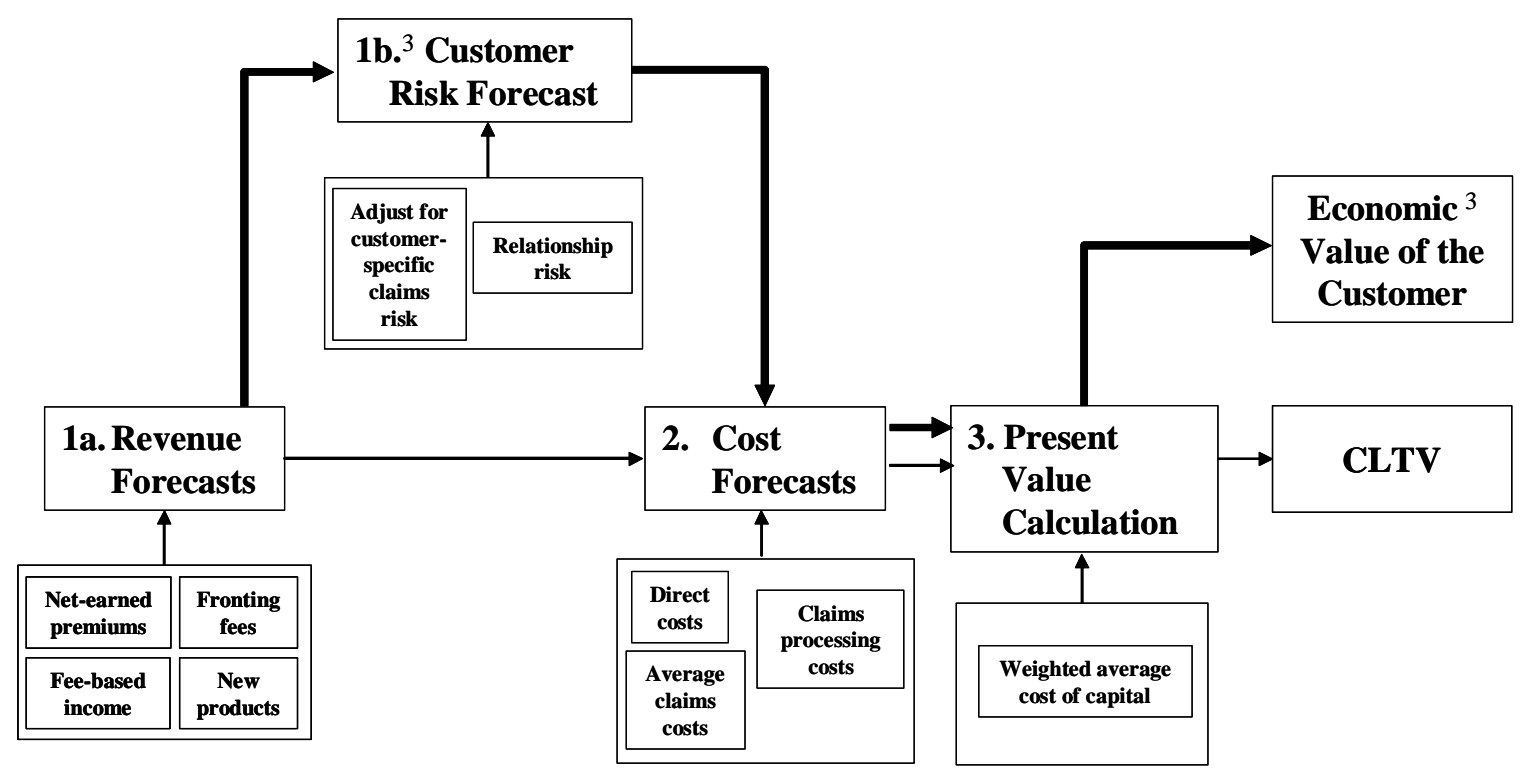

${ }^{3}$ The EV calculation requires a further stage ( $1 \mathrm{~b}$ : Customer risk forecast) and is discussed in detail in the next section. 
Figure 5: Revenue and Claims Cost Forecasts for Customers B and L

\begin{tabular}{|l|c|c|c|c|}
\hline & Year 1 & Year 2 & Year 3 & Year 4 \\
\hline Customer B & & & & \\
\hline Revenue streams (£'000) & & & & \\
\hline Net earned premium (NEP) & 349 & 698 & 831 & 914 \\
\hline Portfolio average claims cost (\% NEP) & $67 \%$ & $67 \%$ & $67 \%$ & $67 \%$ \\
\hline Forecast NEP after claims & $\mathbf{1 1 5}$ & $\mathbf{2 3 0}$ & $\mathbf{2 7 4}$ & $\mathbf{3 0 1}$ \\
\hline Other revenues & 282 & 441 & 482 & 524 \\
\hline Forecast Revenues (£'000) & $\mathbf{3 9 7}$ & $\mathbf{6 7 1}$ & $\mathbf{7 5 6}$ & $\mathbf{8 2 5}$ \\
\hline \multicolumn{2}{|l|}{} & & & \\
\hline Customer L & & & & \\
\hline Revenue streams (£'000) & 73 & 71 & 83 & 91 \\
\hline Net earned premium (NEP) & $67 \%$ & $67 \%$ & $67 \%$ & $67 \%$ \\
\hline Portfolio average claims cost (\% NEP) ${ }^{4}$ & $\mathbf{2 4}$ & $\mathbf{2 3}$ & $\mathbf{2 8}$ & $\mathbf{3 0}$ \\
\hline Forecast NEP after claims & 93 & 93 & 108 & 119 \\
\hline Other revenues & $\mathbf{1 1 7}$ & $\mathbf{1 1 6}$ & $\mathbf{1 3 6}$ & $\mathbf{1 4 9}$ \\
\hline Forecast Revenues (£'000) &
\end{tabular}

\footnotetext{
${ }^{4}$ This is the forecast cost of doing business across the company. Because claims occur, it is prudent to adjust the revenue stream from NEP for claims at a company level based on a forecast portfolio average for key account customers of $67 \%$ of NEP.
} 
Figure 6: Costs-to-serve Forecasts for Customers B and L

\begin{tabular}{|l|c|c|c|c|}
\hline & Year 1 & Year 2 & Year 3 & Year 4 \\
\hline Customer B & & & & \\
\hline Costs-to-serve(£'000) & & & & \\
\hline Underwriting services & n/a & 172 & 189 & 207 \\
\hline Claims & n/a & 21 & 23 & 25 \\
\hline Network & n/a & 113 & 116 & 119 \\
\hline Total Costs-to-Serve & $\mathbf{2 5 0}$ & $\mathbf{3 0 6}$ & $\mathbf{3 2 8}$ & $\mathbf{3 5 1}$ \\
\hline \multicolumn{5}{|l}{} \\
\hline Customer L & & & \\
\hline Costs-to-serve (£'000) & 42 & 42 & 42 & 42 \\
\hline Underwriting services & 8 & 8 & 8 & 8 \\
\hline Claims & 23 & 23 & 23 & 23 \\
\hline Network & $\mathbf{7 3}$ & $\mathbf{7 3}$ & $\mathbf{7 3}$ & $\mathbf{7 3}$ \\
\hline Total Costs-to-Serve &
\end{tabular}


Figure 7: CLTV for Customers B and L

\begin{tabular}{|c|c|c|c|c|}
\hline & Year 1 & Year 2 & Year 3 & Year 4 \\
\hline \multicolumn{5}{|l|}{ Customer B } \\
\hline Forecast Revenues (£'000) ${ }^{5}$ & 397 & 671 & 756 & 825 \\
\hline Total Costs-to-Serve & 250 & 306 & 328 & 351 \\
\hline Profit & 147 & 365 & 428 & 474 \\
\hline $\begin{array}{l}\text { Discount factor (weighted } \\
\text { average cost of capital) @ } 4.8 \%\end{array}$ & .954 & .910 & .869 & .829 \\
\hline Present value & 140 & 332 & 372 & 393 \\
\hline \multicolumn{4}{|l|}{ CLTV (£'000) } & 1,237 \\
\hline \multicolumn{5}{|l|}{ Customer L } \\
\hline Forecast Revenues $\left(£^{\prime} 000\right)^{5}$ & 117 & 116 & 136 & 149 \\
\hline Total Costs-to-Serve & 73 & 73 & 73 & 73 \\
\hline Profit & 44 & 43 & 63 & 76 \\
\hline $\begin{array}{l}\text { Discounted (weighted average } \\
\text { cost of capital) @ } 4.8 \%\end{array}$ & .954 & .910 & .869 & .829 \\
\hline Present value & 42 & 39 & 55 & 63 \\
\hline \multicolumn{4}{|l|}{ CLTV (£'000) } & 199 \\
\hline
\end{tabular}

${ }^{5}$ After portfolio claims risk 
Figure 8: The EV of Customers B and L

\begin{tabular}{|l|c|c|c|c|}
\hline & Year 1 & Year 2 & Year 3 & Year 4 \\
\hline Customer B & & & & \\
\hline Revenue streams (£'000) & & & & \\
\hline Net earned premium (NEP) & 349 & 698 & 831 & 914 \\
\hline Customer-specific claims risk (\% NEP) & - & $30 \%$ & $30 \%$ & $30 \%$ \\
\hline Claims risk-adjusted NEP & 349 & 488 & 581 & 640 \\
\hline Other revenues & 282 & 441 & 482 & 524 \\
\hline Claims risk-adjusted Revenues (£'000) & 631 & 929 & 1063 & 1164 \\
\hline Probability of retention \% & $100 \%$ & $100 \%$ & $82 \%$ & $82 \%$ \\
\hline Final risk-adjusted revenues (£'000) & $\mathbf{6 3 1}$ & $\mathbf{9 2 9}$ & $\mathbf{8 7 1}$ & $\mathbf{9 5 4}$ \\
\hline Costs-to-Serve & 250 & 306 & 328 & 351 \\
\hline Risk-adjusted revenues minus costs & $\mathbf{3 8 1}$ & $\mathbf{6 2 3}$ & $\mathbf{5 4 3}$ & $\mathbf{6 0 3}$ \\
\hline Adjusted for cost of capital @ 4.8\% & 363 & 567 & 472 & 500 \\
\hline EV of Customer B (£'000) & & & $\mathbf{1 9 9 2}$ \\
\hline \multicolumn{2}{|l|}{} & & & \\
\hline Customer L & & & & \\
\hline Revenue streams (£'000) & 73 & 71 & 83 & 91 \\
\hline Net earned premium (NEP) & $60 \%$ & $60 \%$ & $60 \%$ & $60 \%$ \\
\hline Claims risk (\% NEP) & 29 & 28 & 33 & 36 \\
\hline Claims risk-adjusted NEP & 93 & 93 & 108 & 119 \\
\hline Other revenues & 122 & 121 & 141 & 155 \\
\hline Claims risk-adjusted Revenues (£'000) & $100 \%$ & $100 \%$ & $79 \%$ & $79 \%$ \\
\hline Probability of retention \% & $\mathbf{1 2 2}$ & $\mathbf{1 2 1}$ & $\mathbf{1 1 1}$ & $\mathbf{1 2 2}$ \\
\hline Final risk-adjusted revenues (£'000) & 73 & 73 & 73 & 73 \\
\hline Customer-specific Costs-to-Serve & $\mathbf{4 9}$ & $\mathbf{4 8}$ & $\mathbf{3 8}$ & $\mathbf{4 9}$ \\
\hline Risk-adjusted revenues minus costs & 47 & 44 & 33 & 41 \\
\hline Adjusted for cost of capital @ 4.8\% & & & $\mathbf{1 6 5}$ \\
\hline EV of Customer L (£'000) & & & \\
\hline
\end{tabular}


Figure 9: Comparing CLTV and EV of key accounts

\begin{tabular}{|c|c|c|c|}
\hline $\begin{array}{c}\text { Key } \\
\text { Account }\end{array}$ & $\begin{array}{c}\text { Perceptions of Profitability } \\
\text { (Interviews Pre-Research) }\end{array}$ & \multicolumn{2}{|c|}{$\begin{array}{c}\text { CLTV and EV } \\
\text { (Post-Research) }\end{array}$} \\
\hline Mean Rank & 4 & 4 & EV Ranking \\
\hline B & 5 & 12 (unprofitable) & 7 \\
\hline C & 6 & 8 & 10 \\
\hline F & 10 & 2 & 4 \\
\hline G & 2 & 1 & 5 \\
\hline H & 3 & 10 (unprofitable) & 12 (unprofitable) \\
\hline J & 1 & 7 & 9 \\
\hline L & 9 & 6 & No longer a key account \\
\hline N & 12 & 11 (unprofitable) & No longer a key account \\
\hline O & 8 & 9 & n/a \\
\hline P & 7 & 5 & n/a ${ }^{6}$ \\
\hline Q & 11 & 3 & Lost customer $^{6}$ \\
\hline R & & & \\
\hline
\end{tabular}

${ }^{6}$ Risk data for key accounts $\mathrm{P}$ and Q were unavailable.

${ }^{7}$ Key account $\mathrm{R}$ was lost as a customer during the period. 